\title{
Penurunan Waktu Tunggu Pelayanan Obat Rawat Jalan Instalasi Farmasi Rumah Sakit Baptis Batu
}

\section{Waiting Time Shortening on Outpatient Medicine Services at Pharmacy Departement of Baptis Hospital Batu}

\author{
Megawati ${ }^{1}$, Lukman Hakim', Dolly Irbantoro ${ }^{2}$ \\ ${ }^{1}$ Program Studi Magister Manajemen Rumah Sakit Fakultas Kedokteran Universitas Brawijaya Malang \\ ${ }^{2}$ Rumah Sakit Baptis Batu
}

\begin{abstract}
ABSTRAK
Lama waktu tunggu pelayanan obat rawat jalan di Instalasi Farmasi RS Baptis Batu sudah lama dikeluhkan oleh pelanggan. Ketidakpuasan karena waktu tunggu yang lama mempengaruhi persepsi tentang kualitas layanan rumah sakit secara keseluruhan dan menurunkan angka kunjungan ke rumah sakit. Penelitian ini mengukur waktu tunggu dan intervensi perbaikan SPO disertai survei kepuasan pelanggan yang berhubungan dengan waktu tunggu pelayanan obat rawat jalan. Metode penelitian menggunakan pre dan post tes dengan pendekatan studi eksperimental pada 119 sampel pengunjung pelayanan obat rawat jalan selama kurun waktu 2 bulan. Pengambilan data dilakukan dengan mengukur waktu tunggu 2 kali sebelum dan sesudah intervensi disertai kepuasan mengenai lamanya waktu tunggu obat dengan menggunakan skala Likert. Analisis waktu tunggu dan kepuasan pelanggan mengenai waktu tunggu sebelum dan sesudah intervensi dilakukan dengan $T$ test berpasangan dan Wilcoxon. Hasil penelitian menunjukkan adanya perbaikan waktu tunggu pelayanan obat jadi dari rerata $56,42 \pm 27,22$ menjadi $23,11 \pm 8,47$ menit $(p<0,05)$ dan obat racikan dari rerata waktu tunggu $83,21 \pm 26,93$ menjadi $48,24 \pm 9,99$ menit $(p<0,05)$. Adanya perbaikan waktu tunggu berdasar jumlah obat jadi dalam 1 resep yaitu untuk 1-2 macam dari 18 menit menjadi 14 menit, 3-5 macam dari rerata 50,85 $\pm 21,06$ menjadi 18,88 $\pm 7,07$ menit dan $\geq 6$ macam dari rerata $62,95 \pm 31,02$ menjadi27,58 $\pm 7,50$ menit. Kepuasan pasien terhadap waktu tunggu antara sebelum dan sesudah intervensi meningkat bermakna $(p<0,05)$. Penyempurnaan SPO, pengaturan petugas disertai sosialisasi menurunkan waktu tunggu pelayanan obat farmasi dan meningkatkan kepuasan pelanggan terhadap waktu tunggu obat secara bermakna.
\end{abstract}

Kata Kunci: Instalasi farmasi, kepuasan pasien, pelayanan obat rawat jalan, waktu tunggu

ABSTRACT

Waiting time duration on outpatient medicine services at Pharmacy Department of Baptis Hospital Batu has long been complained by the customers. Dissatisfaction because of long waiting time affects the perception of the hospital service quality as a whole and reduces the number of hospital visits. This study measures the waiting time and improves the SOP and followed by survey on customer satisfaction relating to improvement of outpatient medicine services. The research method used pre and post test with an experimental approach on a sample of 119 visitors to outpatient medicine services for a period of 2 months. Data collection was conducted by measuring the 2 waiting times before and after the intervention along with satisfaction about the waiting time duration using Likert scale. Analysis of waiting time and customer satisfaction regarding waiting time before and after the intervention was performed by using paired $T$ test and Wilcoxon. The results show an improvement in average waiting times of the medicine services from $56,42 \pm 27,22$ into $23,11 \pm 8,47$ minutes $(p<0,05)$ and compounding medicine from the average waiting time of $83,21 \pm 26,93$ into $48,24 \pm 9,99$ minutes ( $p$ $<0,05)$. There is an improvement in the waiting time based on the number of medicine in a prescription, for $1-2$ items from

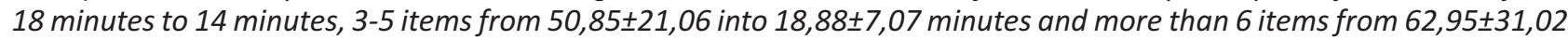
into 27,58 7,50 minutes. Patient satisfaction on the waiting time between before and after the intervention increased significantly $(p<0,05)$. SOP perfection and officer regulation accompanied by socialization decrease the waiting time of medicine services and improve customer satisfaction to waiting time significantly.

Keywords: Outpatient medicine services, patient satisfaction, pharmacy department, waiting time

Jurnal Kedokteran Brawijaya, Vol. 28, Suplemen No. 2, 2015; Korespondensi: Megawati. Program Studi Magister Manajemen Rumah Sakit Fakultas Kedokteran Universitas Brawijaya Malang, Jl. Veteran Malang 65145 Tel. (0341) 569117 Email: megawati_hendrawan@yahoo.com 


\section{PENDAHULUAN}

Pelayanan obat merupakan salah satu bagian yang penting dalam penyelenggaraan pelayanan rumah sakit dan tidak terpisahkan dari pelayanan medik keperawatan. Di rumah sakit, pelayanan obat adalah tanggung jawab dari instalasi farmasi yang bekerja 24 jam. Kecermatan, ketepatan dan kecepatan pelayanan farmasi merupakan indikator penting kepuasan penderita.

Kecepatan pelayanan farmasi tergantung proses yang dilaksanakan pada saat pelayanan farmasi. Proses pelayanan farmasi terdiri dari perencanaan, pengadaan, produksi, penyimpanan sediaan farmasi, dispensing obat, pengendalian mutu dan distribusi serta penggunaan seluruh perbekalan kesehatan di rumah sakit, pelayanan farmasi klinik umum dan spesialis. Proses pelayanan farmasi mencakup pelayanan langsung pada penderita dan pelayanan klinik yang merupakan program rumah sakit secara keseluruhan (1,2). Farmasi rawat jalan adalah apotek yang hanya mengerjakan resep untuk pasien yang telah menerima perawatan medis. Pasien di apotek rawat jalan dilayani oleh Apoteker terlatih, yang akan memberikan petunjuk penggunaan yang tepat dari obatobatan, termasuk kemungkinan efek samping dan tindakan pencegahannya (3). Prosedur di apotek rawat jalan dapat dimodifikasi untuk meningkatkan efisiensi yaitu dengan mengubah alur kerja, memperkenalkan prioritas sistem, dan perubahan pola kepegawaian (4).

Manajemen operasional yang efektif dari apotek rawat jalan sangat penting untuk mencegah atau meminimalkan kepadatan apotek karena dapat menyebabkan kesalahan dalam pemberian obat yang berakibat kematian. Antrian dapat mengurangi tingkat kepuasan pasien. Pengerjaan resep yang terlalu banyak dan tidak sebanding dengan jumlah tenaga farmasi akan membuat staf jenuh, produktivitas menurun dan angka turnover yang tinggi.

Kepmenkes RI No. 129/Menkes/SK/II/2008 tentang Standar Pelayanan Minimal Rumah Sakit pelayanan farmasi menyebutkan beberapa indikator yang harus dipenuhi yaitu (i) waktu tunggu pelayanan obat jadi $\leq 30$ menit, obat racikan $\leq 60$ menit (ii) tidak adanya kejadian kesalahan pemberian obat $100 \%$; (iii) kepuasan pelanggan $\geq 80 \%$; (iv) penulisan resep sesuai formularium $100 \%$ (2). Dari 4 indikator tersebut diatas, yang paling mempengaruhi kepuasan pasien adalah indikator waktu tunggu pelayanan obat. Para pasien mempunyai ekspektasi waktu tunggu yang harus mereka habiskan di apotek. Secara keseluruhan apotek rawat jalan beroperasi dengan tujuan ganda yaitu memberikan obat yang akurat dan tepat waktu (5).

Waktu tunggu pasien didefinisikan sebagai jangka waktu dari saat pasien menyerahkan resep ke Instalasi Famasi Rawat Jalan sampai dengan waktu pasien menerima obat dan meninggalkan instalasi farmasi (6). Menurut survei yang dilakukan oleh Health Services and Outcomes Research, National Healthcare Group Singapore, selain akurasi resep dan keterjangkauan obat, waktu tunggu pelayanan obat sangat mempengaruhi kepuasan pasien yaitu kurang dari 30 menit $(3,6)$. Pengalaman seorang pasien dalam menunggu pelayanan dapat mempengaruhi persepsinya tentang kualitas layanan $(7,8)$. Dalam sebuah penelitian yang dilakukan di University of Southern California, Los Angeles, Amerika Serikat, menunjukkan bahwa keseluruhan kepuasan pasien terhadap jasa farmasi berkaitan erat dengan kepuasan mereka mengenai waktu tunggu (8).
Sebuah studi prospektif enam minggu dilakukan oleh Instalasi farmasi National University Hospital di Singapura pada pasien rawat jalan untuk menilai persepsi dan harapan pelayanan farmasi rawat jalan. Sebanyak 1.273 kuesioner yang didistribusikan ada 413 tanggapan yang dievaluasi. Hasil evaluasi didapatkan bahwa layanan yang paling penting dalam pandangan pasien adalah waktu tunggu pelayanan obat kurang dari 30 menit, pemberian obat-obatan yang tepat dan harga yang wajar. Waktu tunggu rata-rata untuk pelayanan obat adalah 9,5 menit untuk satu sampai dua jenis obat, 16,8 menit untuk tiga sampai lima jenis obat dan 23,9 menit untuk enam atau lebih jenis obat (5).

Data sekunder RS Baptis Batu (RSBB) menunjukkan ada penurunan jumlah kunjungan pasien rawat jalan selama semester I tahun 2014 dibandingkan tahun 2013. Penurunannya mencapai kurang lebih 400-500 pasien/bulan. Penurunan jumlah kunjungan menurunkan pendapatan RSBB (9). Survei kepuasan pasien rawat jalan yang dilakukan tiap bulan mulai Januari-Juni 2014 didapatkan 3 instalasi/bagian dengan peringkat terbawah (paling tidak memuaskan) adalah bagian Farmasi, Parkir dan Aksesibilitas (9). Instalasi Farmasi merupakan unit penyumbang pendapatan RS terbesar nomer tiga setelah Kamar Operasi dan Rawat inap oleh karena itu masalah di Instalasi Farmasi menjadi pilihan utama untuk dianalisis dan dilakukan upaya-upaya perbaikan.

RS Baptis Batu melaksanakan survei lanjutan untuk mengevaluasi kepuasan pasien rawat jalan yang menunggu pelayanan obat di Instalasi Farmasi dengan 4 pertanyaan mengenai yaitu (a) Waktu tunggu pelayanan obat; (b) Pemberian Informasi obat; (c) Ketelitian; dan (d) Keramahan/kesopanan petugas. Ada 2 pilihan jawaban yaitu puas dan tidak puas. Hasil survei pada bulan JanuariJuni 2014 didapatkan ketidakpuasan terbesar adalah pada waktu tunggu pelayanan obat yaitu Januari sebesar $80 \%$, Februari 37,5\%, Maret 50\%, April 34\%,Mei 66,67\%, dan Juni 49,21\% (9).

Data tersebut menunjukkan ada 2 masalah yaitu waktu tunggu pelayanan farmasi rawat jalan yang dianggap lama oleh penderita dan lebih lama dari standar pelayanan minimal (SPM) Instalasi farmasi RS. Analisis akar masalah penyebab waktu tunggu pelayanan obat yang lama dilakukan dengan menggunakan metode Fishbone yang ditinjau dari lima perspektif yaitu Manpower, Money, Material, Methods, dan Environment (10). Hasil analisis tersebut menunjukkan bahwa penyebab utama pelayanan obat yang lama adalah kurangnya sosialisasi alur dan SPO pelayanan obat serta tidak adanya beberapa petugas yang seharusnya ada ditiap-tiap alur oleh karena keterbatasan SDM di Instalasi Farmasi RS Baptis Batu.

Permasalahan ini perlu diatasi dengan melakukan sosialisasi alur dan pembuatan beberapa SPO yang diperlukan serta dilakukan pengisian pos-pos sesuai alur pelayanan obat. Dengan melakukan intervensi tersebut diharapkan waktu tunggu pelayanan obat yang lama dapat diturunkan sehingga akan meningkatkan kepuasan penderita. Penelitian ini dilakukan untuk mengukur dampak intervensi yaitu perbaikan alur dan pembuatan prosedur pelayanan terhadap waktu tunggu pelayanan farmasi pada instalasi rawat jalan.

\section{METODE}

Penelitian dilakukan dengan desain pre dan post tes dengan jumlah subjek sebanyak masing-masing 119 
Tabel 1. Perubahan waktu tunggu pelayanan sesudah intervensi berdasarkan jenis obat dibandingkan dengan standar

\begin{tabular}{|c|c|c|c|c|c|c|c|}
\hline \multirow[b]{2}{*}{ Obat Jadi } & \multicolumn{2}{|c|}{$\leq \mathbf{3 0}$ menit } & \multicolumn{2}{|c|}{$>\mathbf{3 0}$ menit } & \multicolumn{2}{|c|}{ Total } & \multirow[b]{2}{*}{$\mathbf{p}$} \\
\hline & Jumlah & $\begin{array}{c}\text { Mean waktu } \\
\text { tunggu/menit }\end{array}$ & Jumlah & $\begin{array}{c}\text { Mean waktu } \\
\text { tunggu/menit }\end{array}$ & Jumlah & $\begin{array}{l}\text { Mean waktu } \\
\text { tunggu/menit }\end{array}$ & \\
\hline Pre intervensi & $17(21 \%)$ & $21,53 \pm 5,52$ & 64 (79\%) & $58,67 \pm 26,54$ & $81(100 \%)$ & $56,42 \pm 27,22$ & \multirow{2}{*}{$<0,001$} \\
\hline Post intervensi & 64 (79\%) & $20,08 \pm 6,04$ & $17(21 \%)$ & $34,53 \pm 6,33$ & $81(100 \%)$ & $23,11 \pm 8,47$ & \\
\hline \multirow[b]{2}{*}{ Obat Racikan } & \multicolumn{2}{|c|}{$\leq 60$ menit } & \multicolumn{2}{|c|}{$>60$ menit } & \multicolumn{2}{|c|}{ Total } & \multirow[b]{2}{*}{$\mathbf{p}$} \\
\hline & Jumlah & $\begin{array}{l}\text { Mean waktu } \\
\text { tunggu/menit }\end{array}$ & Jumlah & $\begin{array}{l}\text { Mean waktu } \\
\text { tunggu/menit }\end{array}$ & Jumlah & $\begin{array}{c}\text { Mean waktu } \\
\text { tunggu/menit }\end{array}$ & \\
\hline Pre intervensi & $8(21,1 \%)$ & $51,62 \pm 11,90$ & $30(78,9 \%)$ & $91,63 \pm 23,88$ & $38(100 \%)$ & $83,21 \pm 26,93$ & \multirow{2}{*}{$<0,001$} \\
\hline Post intervensi & $33(86,84 \%)$ & $45,93 \pm 8,59$ & $5(13,16 \%)$ & $63,4 \pm 1,51$ & $38(100 \%)$ & $48,24 \pm 9,99$ & \\
\hline
\end{tabular}

pengunjung pelayanan obat di Instalasi Farmasi Rawat Jalan RS Baptis Batu pada bulan September-Oktober 2014. Intervensi yang diberikan berupa penyusunan alur, penjadwalan ulang bagi petugas Instalasi Farmasi sehingga semua pos alur pelayanan resep terisi oleh petugas serta pembuatan dan sosialisasi beberapa SPO pelayanan obat yang diperlukan.

Batasan waktu tunggu yang diukur dalam penelitian ini adalah jangka waktu dari saat pasien menyerahkan resep ke instalasi famasi rawat jalan sampai dengan waktu pasien menerima obat dan meninggalkan instalasi farmasi. Jenis obat ada 2 yaitu obat jadi dan obat racikan. Jumlah obat yang tertulis di setiap resep dengan kategori 1 jumlah obat 1-2, kategori 2 jumlah obat 3-5 dan kategori 3 jumlah obat $\geq 6$. Pengukuran waktu tunggu dilakukan 2 kali, yaitu sebelum dan sesudah dilakukan intervensi dengan menggunakan jam meja digital merk Essa 6603 yang terdapat di Instalasi Farmasi.

Waktu tunggu yang diukur sebelum maupun sesudah intervensi dibedakan jenis resepnya menjadi 2 jenis yaitu resep obat jadi dan racikan yang kemudian dibandingkan dengan Standar Pelayanan Minimal (SPM) RS yang ideal yaitu $\leq 30$ menit (obat jadi) sedangkan untuk obat racikan adalah $\leq 60$ menit. Perhitungan waktu tunggu resep obat jadi disesuaikan dengan kategori jumlah obat dalam 1 resep sebagai berikut: kategori 1 terdiri dari 1-2 macam obat dalam 1 resep, kategori 2 terdiri dari 3-5 macam obat dan kategori 3 terdiri dari $\geq 6$ macam obat (5).

Variabel kepuasan diukur dengan satu indikator yaitu kepuasan terhadap waktu tunggu pelayanan obat dengan pilihan jawaban dalam lima skala Likert. Bagi responden yang menjawab dengan skala 1 atau 2 akan diberikan pertanyaan terbuka dengan ditanyakan alasannya memberi penilaian 1 atau 2. Analisis waktu tunggu dilakukan dengan menggunakan $T$-test berpasangan dan kepuasan pelanggan terhadap waktu tunggu pelayanan obat dilakukan dengan Uji Wilcoxon untuk mengetahui perbedaan antara sebelum dan sesudah intervensi.

HASIL

Seluruh resep yang dievaluasi dalam penelitian ini merupakan resep dari pasien BPJS-K. Berdasarkan jenis obat, baik sebelum dan sesudah intervensi mempunyai proporsi yang sama yaitu $31,9 \%$ obat racikan dan $68,1 \%$ obat jadi. Pembedaan jenis sediaan obat dilakukan untuk mengukur lama waktu tunggu pelayanan obat yang dibedakan sesuai SPM.

\section{Perubahan Waktu Tunggu Pelayanan Sesudah Intervensi} Berdasarkan Jenis Obat

Hasil memperlihatkan bahwa proporsi resep dengan waktu tunggu pelayanan obat jadi pre intervensi lebih lama dari SPM sebesar $79 \%$ sedangkan post intervensi hanya sebesar $21 \%$. Hal serupa ditemukan juga pada waktu tunggu pelayanan obat racikan. Proporsi resep dengan waktu tunggu lebih lama dari SPM sebelum intervensi sebesar 78,9\% sedangkan sesudah intervensi menurun menjadi sebesar $13,16 \%$. Secara keseluruhan rerata waktu tunggu obat jadi sebelum intervensi sebesar $56,42 \pm 27,22$ dan sesudah intervensi menurun secara signifikan menjadi $23,11 \pm 8,47(p<0,001)$ dan juga lebih pendek dari SPM. Pada pelayanan obat racikan juga ditemukan penurunan signifikan $(p<0,001)$ rerata waktu tunggu sebelum intervensi $(83,21 \pm 26,93)$ menjadi $(48,24 \pm 9,99)$ sesudah intervensi. Waktu tunggu obat racikan sesudah intervensi juga lebih cepat dari SPM (60 menit).

Lamanya waktu tunggu pelayanan obat dihitung berdasar jumlah obat yang terdapat dalam 1 resep untuk jenis sediaan obat jadi pre dan post intervensi. Jumlah responden masing-masing 81 responden dan dilakukan analisis waktu tunggu pelayanan obat. Secara deskriptif hasil menunjukkan bahwa sebelum intervensi, semakin banyak jumlah obat dalam satu resep, semakin panjang waktu tunggu pelayanan obat. Sesudah intervensi meskipun waktu tunggu pelayanan obat yang lebih banyak juga lebih lama namun bila dibandingkan sebelum intervensi, waktu yang diperlukan jauh lebih pendek baik pada resep dengan 1-2 macam obat (14 menit, $p<0,001$ ), 35 macam obat (19 menit, $p<0,001),>6$ macam obat $(28$ menit, $p<0,001)$ dan perbedaan diantaranya juga lebih kecil.

Tabel 2. Perbedaan waktu tunggu pelayanan obat jadi berdasar jumlah obat dalam 1 resep sesudah intervensi

\begin{tabular}{|c|c|c|c|c|c|c|c|c|}
\hline & \multicolumn{2}{|c|}{ 1-2 macam } & \multicolumn{2}{|c|}{ 3-5 macam } & \multicolumn{2}{|c|}{$\geq 6$ macam } & \multicolumn{2}{|c|}{ Total } \\
\hline & Jumlah & $\begin{array}{l}\text { Mean waktu } \\
\text { tunggu/menit }\end{array}$ & Jumlah & $\begin{array}{c}\text { Mean waktu } \\
\text { tunggu/menit }\end{array}$ & Jumlah & $\begin{array}{c}\text { Mean waktu } \\
\text { tunggu/menit }\end{array}$ & Jumlah & $\begin{array}{l}\text { Mean waktu } \\
\text { tunggu/menit }\end{array}$ \\
\hline Pre intervensi & $1(1,24 \%)$ & 18 & $40(49,38 \%)$ & $50,85 \pm 21,06$ & $40(49,38 \%)$ & $62,95 \pm 31,02$ & $81(100 \%)$ & $56,42 \pm 27,22$ \\
\hline Post intervensi & $1(1,24 \%)$ & 14 & $40(49,38 \%)$ & $18,88 \pm 7,07$ & $40(49,38 \%)$ & $27,58 \pm 7,50$ & $81(100 \%)$ & $23,11 \pm 8,47$ \\
\hline p & \multicolumn{2}{|c|}{$<0,001$} & \multicolumn{2}{|c|}{$<0,001$} & \multicolumn{2}{|c|}{$<0,001$} & & \\
\hline
\end{tabular}


Perubahan Kepuasan Pelanggan terhadap Waktu Tunggu Pelayanan Obat Sesudah Intervensi

Respon kepuasan responden dalam 5 skala Likert dilakukan pengelompokan yaitu yang menjawab 1 (sangat tidak puas) dan 2 (tidak puas) dikelompokkan sebagai jawaban yang tidak puas terhadap waktu tunggu pelayanan obat sedangkan yang menjawab 3 (cukup puas), 4(puas), dan 5 (sangat puas) dikelompokkan sebagai jawaban yang puas terhadap waktu tunggu. Tabel 3 menunjukkan bahwa proporsi responden yang puas terhadap pelayanan farmasi meningkat dari 50,4\% menjadi $81,5 \%$ sesudah intervensi.

Tabel 3. Analisis diskriptif perubahan kepuasan terhadap waktu tunggu pelayanan obat

\begin{tabular}{lcccccc}
\hline & \multicolumn{2}{c}{ Likert 1-2 (tidak puas) } & \multicolumn{2}{c}{ Likert 3-5 (puas) } & \multicolumn{2}{c}{ Total } \\
\cline { 2 - 7 } & Jumlah & $\begin{array}{c}\text { Responden } \\
\text { (\%) }\end{array}$ & Jumlah & $\begin{array}{c}\text { Responden } \\
\text { (\%) }\end{array}$ & Jumlah & $\begin{array}{c}\text { Responden } \\
\text { (\%) }\end{array}$ \\
\hline Pre intervensi & 59 & 49,6 & 60 & 50,4 & 119 & 100 \\
Post intervensi & 22 & 18,5 & 97 & 81,5 & 119 & 100 \\
\hline
\end{tabular}

Dilakukan uji Wilcoxon yaitu uji non parametrik yang digunakan untuk menguji apakah dua variabel yang saling berpasangan mempunyai perbedaan hasil yang nyata atau tidak. Hasil uji menunjukkan kepuasan responden sesudah intervensi yang lebih kecil dari pada sebelum intervensi sebanyak 6 orang responden, kepuasan responden sesudah intervensi yang lebih besar dari pada sebelum intervensi sebanyak 57 responden, dan kepuasan responden sesudah intervensi yang sama dengan sebelum intervensi sebanyak 56 responden.

Hasil uji Wilcoxon kepuasan pelanggan terhadap waktu tunggu pelayanan obat post intervensi nilai $Z$ hitung sebesar $6.249^{a}$ dan signifikansi sebesar 0,000 . Karena $Z$ hitung mutlak lebih besar dari ztabel $\left(6.249^{\mathrm{a}}>1,645\right)$ dan $\mathrm{p}<0,001$ menunjukkan perbedaan nyata kepuasan pelanggan pre dan post intervensi Hal ini berarti bahwa terdapat perbaikan signifikan kepuasan pelanggan terhadap waktu tunggu pelayanan obat sesudah intervensi.

\section{DISKUSI}

Pemendekan waktu tunggu sangat penting dan merupakan metode yang efektif untuk peningkatan kualitas pelayanan. Salah satu jenis pelayanan yang memberikan dampak pada kepuasan penderita adalah waktu tunggu dan salah satunya pelayanan farmasi. Lama waktu tunggu pelayanan obat rawat jalan di Instalasi Farmasi RSBB sudah lama dikeluhkan oleh pelanggan. Berdasarkan analisis Fishbone ditemukan beberapa faktor yang menjadi akar masalah. Faktor manusia (man) yaitu tidak adanya petugas penerima resep, petugas tidak konsisten mengikuti alur pelayanan obat, petugas kurang patuh pada jobs disk sesuai alur pelayanan karena rangkap tugas yang disebabkan kurangnya SDM terutama pada hari-hari praktek dokter spesialis yang banyak (hari Jumat dan Sabtu) serta petugas kurang tanggap terhadap keluhan pasien. Penelitian di Sahlgrenska University Hospital Clinics Gothenburg, Sweden menemukan bahwa faktor manusia memang memegang peranan yang paling penting tetapi bila pemecahannya dengan menambah
SDM maka ini bukan merupakan pilihan dimasa depan karena perkembangan tehnologi medis dan perubahan demografi (11). Mendapatkan komitmen manajemen dan melibatkan semua orang dapat memperpendek waktu tunggu (11). Apabila rumah sakit mempunyai tenaga kerja terbatas, maka perlu untuk mereformasi alur pelayanan obat yang dapat memperpendek waktu tunggu. Apotik rawat jalan di pusat medis Taiwan digunakan sebagai studi kasus dalam menentukan bagaimana mempersingkat waktu tunggu pelayanan obat meskipun jumlah staf dan fasilitasnya terbatas (12).

Faktor metode (method) yaitu belum lengkapnya SPO pelayanan resep obat rawat jalan di instalasi farmasi, kurangnya sosialisasi SPO dan ketidakjelasan jobs disk. Adanya pemberkasan yang tidak efisien dan efektif serta penjadwalan petugas yang belum sesuai dengan kebutuhan pelayanan obat. Saat ini sudah ada 8 SPO sesuai dengan alur resep yaitu SPO pembuatan etiket obat, penanganan resep yang tidak terbaca, skrining resep, telaah obat, pengadaan obat bila tidak tersedia, pengadaan obat di luar formularium, penyerahan obat, dan Komunikasi Informasi Edukasi (KIE) rawat jalan. Meskipun demikian masih ada beberapa SPO yang perlu dibuat supaya alur penyiapan obat menjadi lebih cepat.

Pada dasarnya, setiap resep pasien yang diterima apotek rawat jalan akan menjalani 5 proses internal, yaitu pendaftaran, pemberian etiket, pembuatan obat, pemeriksaan, dan pemberian obat ke pasien. Setelah mencapai apotek rawat jalan, pasien akan antri untuk menunggu gilirannya menyerahkan resep (13). Penelitian di The University of North Carolina Hospitals and Clinics (UNCH) telah menunjukkan kebutuhan untuk meningkatk analur kerja diapotek rawat jalan. Pengaturan ini untuk membantu apoteker lebih efektif menggunakan waktu mereka untuk interaksi langsung dengan pasien lebih dari kegiatan dispensing teknis (13). Dengan meningkatnya biaya kesehatan, populasi yang menua, dan kekurangan tenaga terlatih hal ini menjadi semakin penting bagi manajemen farmasi rumah sakit diantaranya dengan penjadwalan kerja (14).

Faktor material yaitu obat BPJS sering tidak ada sehingga harus menunggu obatnya ada atau diganti dengan merk lain dan harus dikonsultasikan dengan dokter penulis resep sehingga memperlama waktu. Jenis resep obat racikan juga memerlukan waktu untuk penyediaannya. Beberapa alat seperti blender obat sudah waktunya diganti dan kalkulator masih kurang. Faktor lingkungan (environment) yaitu kursi ruang tunggu kurang nyaman, ruang pelayanan obat yang sempit serta petunjuk pelayanan obat untuk pengunjung yang kurang jelas juga menambah lamanya waktu tunggu pelayanan obat rawat jalan. Faktor uang (money) yaitu masih belum tersedianya anggaran untuk renovasi ruang pelayanan obat rawat jalan dan penggantian kursi ruang tunggu.

Ada beberapa faktor yang dapat diatasi dalam waktu singkat tetapi ada faktor-faktor yang masih menunggu tersedianya anggaran. Intervensi yang telah dilakukan dalam penelitian ini meliputi (i) menganalisis lamanya waktu tunggu pelayanan obat rawat jalan di IFRS dengan mengukur secara langsung lamanya pelayanan obat sebelum intervensi dibandingkan dengan SPM Instalasi Farmasi RS; (ii) Membuat SPO untuk tiap-tiap pos yang ada pada alur pelayanan resep umum/BPJS rawat jalan dan mensosialisasikan kepada seluruh staf instalasi farmasi rawat jalan; (iii) pemberkasan yang banyak dan tidak 
sesuai dengan deskripsi tugas petugas instalasi farmasi diserahkan pada petugas yang seharusnya (bagian pelayanan asuransi); (iv) melakukan penjadwalan ulang jam kerja petugas farmasi rawat jalan dan menambah tenaga asisten apoteker ataupun juru racik dari staf farmasi rawat inap pada hari-hari penerimaan resep yang banyak dan melakukan sosialisasi job deskripsi yang sesuai dengan pos-pos yang ada pada alur pelayanan obat; (v) pembelian blender obat dan kalkulator. Manajemen operasional yang efektif dari apotek rawat jalan sangat penting untuk mencegah atau meminimalkan kepadatan apotek. Kepadatan tidak diinginkan karena dapat menyebabkan kesalahan dalam pemberian obat bahkan menyebabkan kematian. Waktu tunggu yang panjang, yang disebabkan oleh antrian dapat mengurangi tingkat kepuasan pasien (3). Penelitian yang dilakukan di Singapore General Hospital pada Departemen Farmasi merekomendasikan rencana penjadwalan tenaga kerja baru, yang cocok dengan ketersediaan tenaga kerja dan pola kedatangan pasien (3). Melalui analisi salur kerja yang ada difarmasi rawat jalan, peluang untuk mengoptimalkan penggunaan nilai tambah waktu apoteker dalam proses pengeluaran diidentifikasi dapat dilakukan (13).

Hasil penelitian menunjukkan bahwa sesudah dilakukan intervensi lamanya waktu tunggu pelayanan obat rawat jalan baik sediaan obat jadi maupun racikan mengalami penurunan yang signifikan dan sudah lebih cepat dibandingkan standar pelayanan minimal RS. Meskipun demikian masih ada $21 \%$ obat jadi yang belum memenuhi SPM, sehingga perlu diteliti kembali faktor-faktor lain apa yang mempengaruhi kecepatan pelayanan walaupun sudah dilakukan beberapaperbaikan. Faktor penyebab potensial yang mungkin terjadi adalah kerjasama tim secara konsisten belum menjadi budaya organisasi di rumah sakit. Proses pengisian resep dapat dikelola lebih efektif sehingga mengurangi waktu tunggu dengan mempersatukan beberapa prosedur. Perlu pelatihan karyawan, evaluasi, dan reward system yang sesuai untuk mematuhi proses baru. Adanya pergantian staf farmasi karena berhenti bekerja, banyaknya jumlah resep yang diproses pada waktu tertentu, jumlah pelanggan menunggu, kompleksitas resep (racikan), masalah asuransi, dan resep salah (7).

\section{DAFTAR PUSTAKA}

1. Siregar CJP dan Amalia L. Farmasi Rumah Sakit, Teori dan Penerapan. Jakarta: Penerbit EGC; 2004.

2. Menteri Kesehatan Republik Indonesia. Kemenkes: 1197/MENKES/SK/2004 tentang Standar Pelayanan Farmasi di Rumah Sakit. Jakarta: Kementerian Kesehatan RI; 2004.

3. Choon $\mathrm{OH}$, Leng CW, Ai WJ, and Chai TM. Evaluation of Manpower Scheduling Strategies at Outpatient Pharmacy with Discrete-Event Simulation. OR Insight. 2013; 26(1): 71-84.

4. Reynolds M, Vasilakis C, McLeod M, et al. Using Discrete Event Simulation to Design a More Efficient Hospital Pharmacy for Outpatients. Health Care Management Science. 2011; 14(3): 223-236.

5. Tam VHY and Lim MM. Patients' Perceptions and Expectations of Outpatient Pharmacy Services in a Teaching Hospital. International Journal of Pharmacy
Untuk lebih memenuhi kepuasan pasien terhadap waktu tunggu obat jadi maka dilakukan juga penghitungan waktu tunggu berdasar jumlah obat dalam 1 resep dan dikelompokkan menjadi 3 kelompok yaitu 1-2 macam obat, 3-5 macam obat dan $\geq 6$. Hasil penghitungan waktu post intervensi masih jauh dari ekspektasi dan persepsi pasien pada penelitian yang pernah dilakukan oleh Tam dan Lim di Singapura. Pada penelitian tersebutuntuk 1-2 macam obat hanya memerlukan waktu pelayanan 9,5 menit, 3-5 macam obat 16,8 menit dan $>6$ macam obat 23,9 menit. Hal ini kemungkinan disebabkan upaya-upaya intervensi belum sepenuhnya dijalankan sesuai standar yang ditetapkan dan masih perlu waktu bagi petugas farmasi untuk memahami jobdisk dan melakukan perubahan. Hal ini dapat dijadikan dasar untuk meneliti lagi kemungkinan adanya faktor-faktor lain yang mengurangi kecepatan pelayanan obat rawat jalan di Instalasi Farmasi RSBB.

Salah satu faktor penentu waktu tunggu pelayanan farmasi adalah jumlah petugas Instalasi Farmasi Rawat Jalan. The Taichung General Veterans Hospital di Taiwan digunakan sebagai studi kasus dalam menentukan bagaimana mempersingkat waktu tunggu pelayanan obat meskipun jumlah staf dan fasilitasnya terbatas (12). Rumah sakit yang hanya memiliki tenaga kerja terbatas, mempunyai strategi melakukan perubahan dan penyesuaian alur pelayanan obat untuk memperpendek waktu tunggu (12). Dengan adanya pengaturan kerja maka Apoteker lebih efektif menggunakan waktu mereka untuk interaksi langsung dengan pasien lebih dari kegiatan dispensing teknis (13).

Untuk uji kepuasan pasien terhadap lamanya waktu tunggu pelayanan obat rawat jalan di Instalasi Farmasi RSBB dilakukan uji Wilcoxon dan didapatkan hasil bahwa kepuasan pelanggan meningkat setelah dilakukan intervensi dengan menunjukkan penurunan yang bermakna $(p<0,05)$. Intervensi dengan melakukan penyempurnaan dan sosialisasi SOP serta mengatur kembali tugas semua staf di Instalasi Farmasi RSBB menurunkan waktu tunggu dan kepuasan pasien terhadap waktu tunggu pelayanan obat secara bermakna meskipun masih perlu mencari faktor lainnya untuk lebih meningkatkan kepuasan pasien.

Practice. 1997; 5(3): 128-132.

6. Tan WS, Chua SL, Yong KW, and Wu TS. Impact of Pharmacy Automation on Patient Waiting Time: An Application of Computer Simulation. Annals Academy of Medicine Singapore. 2009; 38(6): 501-507.

7. Slowiak JM, Huitema BE, and Dickinson AM. Reducing Wait Time in a Hospital Pharmacy to Promote Customer Service. Quality Management in Health Care. 2008; 17(2): 112-127.

8. Afolabi MO and Erhun WO. Patients' Response to Waiting Time in an Out-Patient Pharmacy in Nigeria. Tropical Journal of Pharmaceutical Research. 2005; 2(2): 207-214.

9. Rumah Sakit Baptis Batu. Laporan Kegiatan RS Baptis Batu Semester I. Batu: RS BATU; 2014.

10. Parayitam S, Desai K, Desai MS, and Eason MK. Teaching the Ishikawa's "Fishbone" as a Planing Tool: Responsibility and Action Planning Matrices Applied to 
Airport Security and Network Security. Academy of Educational Leadership Journal. 2009; 13(1): 19-35.

11. Eriksson H, Bergbrant I, Berrum I, and Mörck B. Reducing Queues: Demand and Capacity Variations. International Journal of Health Care Quality Assurance. 2011; 24(8): 592-600.

12. Chou YC, Chen BY, Tang YY, et al. Prescription-Filling Process Reengineering of an Outpatient Pharmacy.
Journal of Medical Systems. 2012; 36(2): 893-902.

13. Jenkins A and Eckel SF. Analyzing Methods for Improved Management of Workflow in an Outpatient Pharmacy Setting. American Journal of Health-System Pharmacy. 2012;69(11):966-971.

14. Spry CW and Lawley MA. Evaluating Hospital Pharmacy Staffing and Work Scheduling Using Simulation. Proceedings of the 37th conference on Winter simulation; 2005: hal. 2256-2263 